\title{
GROUND DEFORMATION IN GRANADA HILLS AND MISSION HILLS RESULTING FROM THE JANUARY 17, 1994, NORTHRIDGE, CALIFORNIA, EARTHQUAKE
}

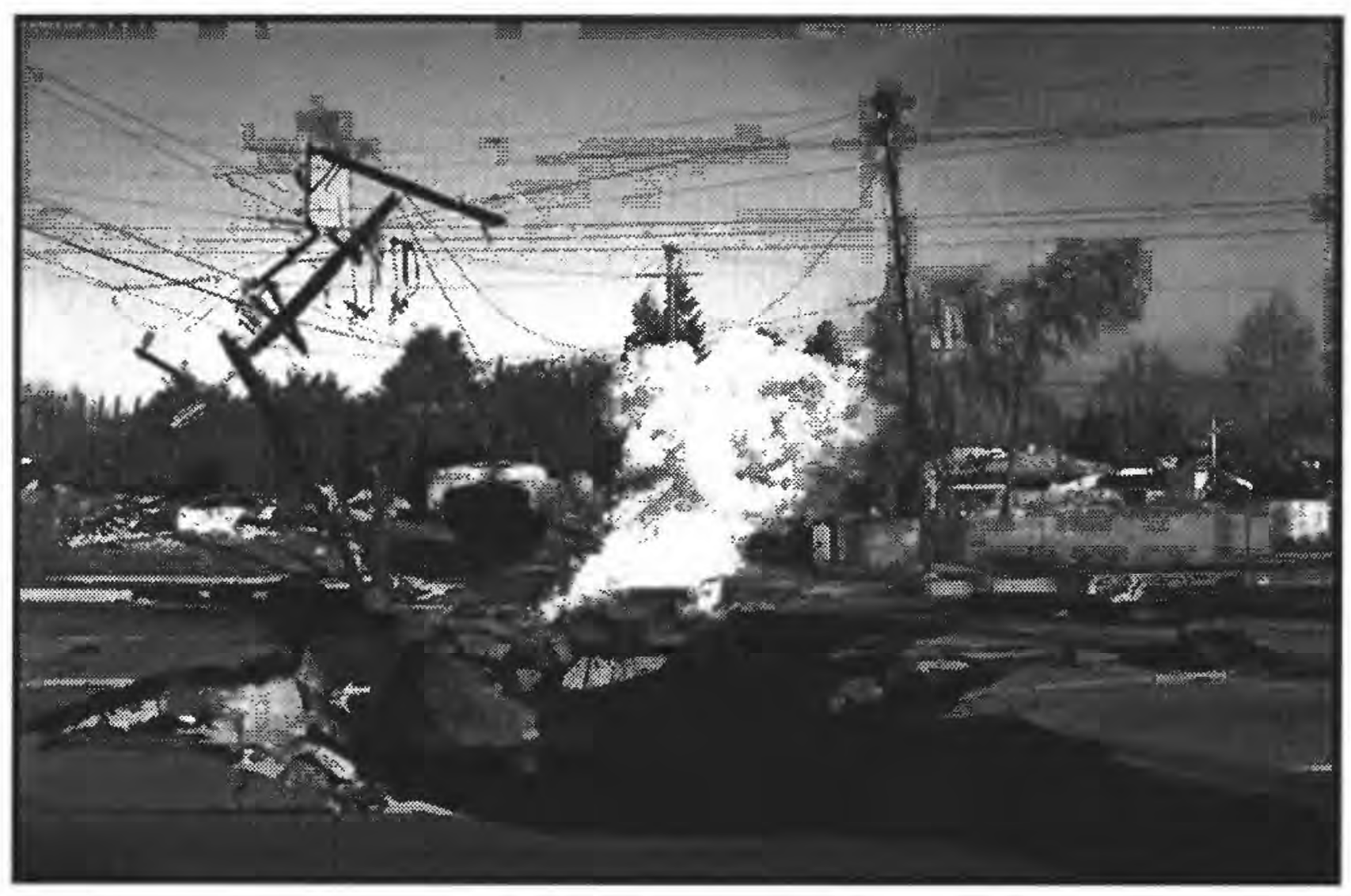

\section{U.S. GEOLOGICAL SURVEY OPEN-FILE REPORT 95-62}

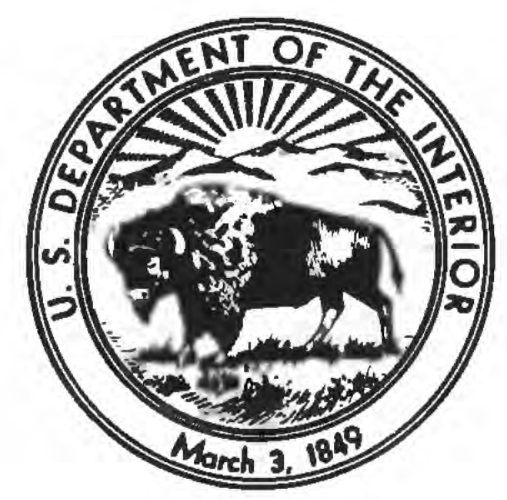




\title{
U.S. DEPARTMENT OF THE INTERIOR U.S. GEOLOGICAL SURVEY
}

\section{GROUND DEFORMATION IN GRANADA HILLS AND MISSION HILLS RESULTING FROM THE JANUARY 17, 1994, NORTHRIDGE, CALIFORNIA, EARTHQUAKE}

by

\author{
Suzanne Hecker, Daniel J. Ponti, Cristofer D. Garvin, Thomas J. Powers, Thomas E. Fumal, \\ John C. Hamilton, Robert V. Sharp, \\ Michael J. Rymer, Carol S. Prentice, ${ }^{1}$ and Francesca R. Cinti ${ }^{2}$
}

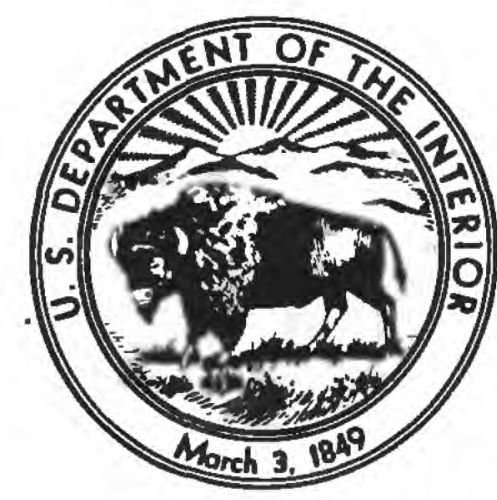

OPEN-FILE REPORT 95-62

This report is preliminary and has not been reviewed for conformity with U.S. Geological Survey editorial standards or with the North American Stratigraphic Code. Any use of trade, product, or firm names is for descriptive purposes only and does not imply endorsement by the U.S. Government.

$$
\begin{gathered}
\text { Menlo Park, California } \\
1995
\end{gathered}
$$


Copies of this report can be purchased from:

U.S. Geological Survey

Earth Science Information Center

Open-File Reports Section

Box 25286, MS 517

Denver Federal Center

Denver, CO 80225 


\section{ABSTRACT}

The M 6.7 Northridge earthquake of January 17, 1994, produced concentrated ground deformation and associated damage in a 5-km-long linear belt within suburban Granada Hills and Mission Hills in the northern San Fernando Valley. Small-displacement cracks comprise discrete zones with characteristics that reflect control by local physiographic and near-surface conditions. Several semi-arcuate zones of tension cracks and a zone of compression (expressed by crumpled pipelines and crushed pavement) formed in Holocene alluvium on the gently sloping piedmont west of Bull Canyon. These observations, along with evidence from trenches and surveys of road deformation, point to shallow mass movement as the primary cause of deformation in the area. A combination of tension cracks and compressional buckles developed along the pre-development course of Bull Creek in lower Bull Canyon and above filled tributary drainages farther east. The relation of this deformation to stream channels and, locally, to small sand boils implicates liquefaction, sediment compaction, and/or lurching of surficial deposits as the likely cause(s) of deformation. Tension cracks also developed on the moderately steep flank of the Mission Hills anticline at the east end of the deformation belt. Locally, these features are clearly related to slope failure, but cracks in the largest set also follow downslope-dipping bedding and thus could be an expression of slip accommodation related to possible coselsmic folding in the anticllne. The various characteristics of deformation observed in the Granada Hills-Mission Hills belt are consistent with one or more types of shallow-seated phenomena and are not consistent with a tectonic faulting origin. The nature of these phenomena implicates strong ground shaking as a primary driving mechanism for deformation.

The distribution of ground deformation strongly reflects the distrlbution of damage (to roads, utility lines, and structures) in the Granada Hills-Mission Hills-area. This correlation points to the value of understanding factors that control the location of shaking-induced ground failures (such as location of concealed thrust faults), as well as how frequently these failures occur. Understanding the risk posed by this hazard requires more work, however; both locally, to better establish recurrence times, and regionally, to identify the extent of the hazard.

\section{INTRODUCTION}

The M6.7 Northridge earthquake was the largest earthquake to strike the Los Angeles metropolitan region in 23 years and produced an estimated $\$ 20$ billion in direct economic losses (Goltz, 1994). Most of the damage to buildings and infrastructure in the region can be attributed to the effects of strong ground shaking, but damage in Granada Hills and Mission Hills, located approximately $10 \mathrm{~km}$ northeast of the epicenter in the northern San Fernando Valley, is largely associated with permanent ground deformation (fig. 1). Ground cracks with movement in the centimeter to decimeter range displaced the foundations of houses, fractured swimming pools, broke apart sidewalks and streets, and ruptured utility lines within a belt $\sim 5 \mathrm{~km}$ long and several hundred meters wide. The deformation was concentrated in certain areas within the belt, and formed locally complex associations of ground and pavement cracks, graben, compressional features such as buckled pavement and tented sidewalks, and lateral offsets of sidewalks and curbs.

Immediately following the earthquake, the U.S. Geological Survey deployed a team of geologists from Menlo Park to the San Fernando Valley to search for and document possible surface faulting. The results of our initial reconnaissance, along with the preliminary seismic and geodetic data for the earthquake, clearly indicated that the Granada HillsMission Hills deformation belt was not the result of surface faulting on the source fault of the earthquake. However, the belt does exhibit some general characteristics suggestive of sympathetic movement or triggered slip. Principal among these are the belt's position both in the hanging-wall of the causative fault and along or near surface projections of the Mission Hills fault zone and anticline (fig. 1).

To determine whether the origin of deformation is secondary surface faulting, or shaking-induced ground failure, we embarked upon a detailed field investigation of the area. In addition to determining the cause(s) of deformation, we sought to assess how the ground cracks relate to the widespread infrastructure and structural damage in the area. Between January 17 and mid-March of 1994, our field investigations involved surface-crack mapping at a scale of 1:1000, compilation of initial damage surveys, and road surveys to document the displacement field associated with the deformation.

The main purpose of this report is to present our map and damage-survey data at scales sufficient to show patterns of individual cracks and relation of cracks to the built environment (1:5000 and 1:2000 scale, plates 1 and 2 , respectively). Results from other facets of our work in the area (i.e., the road-deformation surveys and crack-zone trenching), as well as a more in-depth discussion of conclusions drawn from all of our studies to date, are contained in a more comprehensive report (Hecker, Ponti, and others, 1995).

\section{STUDY METHODS AND CONSTRAINTS}

Our study comprised an initial field reconnaissance to help define the extent of ground deformation in the piedmont areas of Granada Hills and Mission Hills (fig. 1, inset map), followed by mapping on 1:1000-scale black-and-white aerial photography flown for this study on January 21 and 22, 1994. Although many ground cracks are found in uplands 


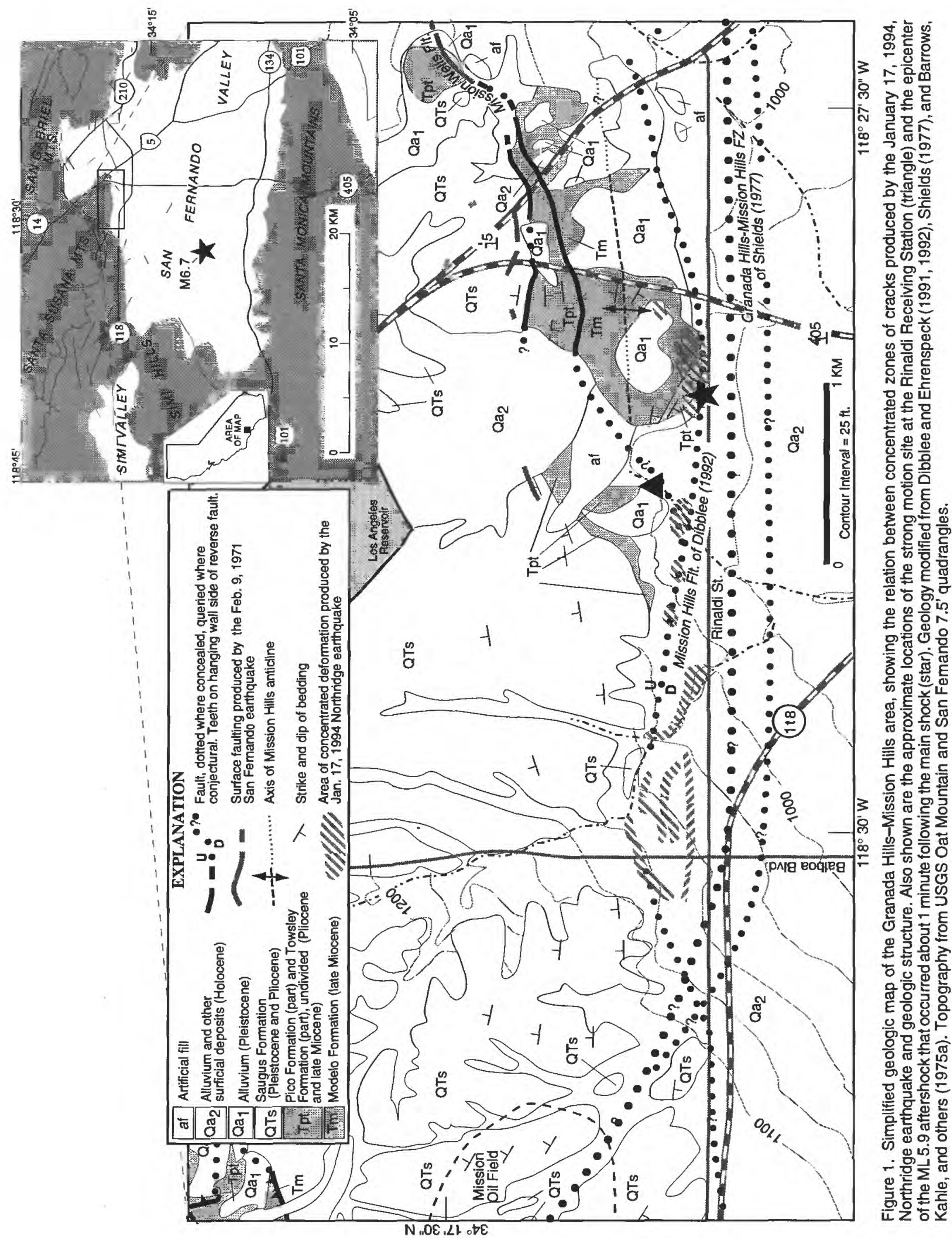


north of to the study area, these cracks have not been studied in detail because they appear to be principally the result of shaking-induced slope failure.

Mapping in Granada Hills and Mission Hills was a logistical challenge because many of the surface cracks either formed in houses, yards, or other private property where access was restricted, or broke apart roads and sidewalks that underwent repairs within days or weeks of the earthquake. Private repair work by homeowners, vehicular traffic on roads, and rainstorm runoff across bare ground also degraded or destroyed cracks during the time period of our study. Another difficulty of working in a suburban environment is that the presence of buildings, fences, cars and vegetation, together with the shadows cast by these objects, either blocks or obscures the aerial view of many cracks.

Despite limitations of visibility, many surface cracks were identified by inspection of the post-earthquake aerial photographs. By using 20-40x or greater magnification and stereo viewing, we were able to identify on the photographs most of the significant cracks that cross roads and concrete surfaces, such as walkways, driveways, and pool decks, except where the cracks are obscured by shadows or vegetation. Photo inspection also allowed us to map cracks in places where they were obliterated shortly after the photos were taken, and aided us in locating and mapping cracks that cross open ground.

Photo inspection was followed by field mapping, which involved checking the photo interpretations, measuring amounts and directions of slip, and mapping in areas obscured on the photos. Gaps in our mapping are likely to exist: 1) along recognized crack trends where we were not able to enter homes or yards, 2) where downed fences or piles of construction material covered the ground, and 3) elsewhere in the study area where small zones of isolated çracks may not have been visible on our photography.

To provide information on the distribution of cracks with respect to the built environment, we have compiled our 1:1000-scale mapping onto a 1:5000-scale photomosaic of the study area (plate 1). We have also compiled our mapping in the area west of Bull Canyon, where the deformation and damage are most concentrated, onto an enlarged aerial photograph ( 1:2000 scale; plate 2$)$. The base imagery for both plates comes from 1:12,000-scale color aerial photography of the epicentral region flown only a few hours after the earthquake (by I.K. Curtis, Inc. of Burbank, California). The photography is unrectified and thus contains spatial distortions related to radial distortion, camera angle, and topography. Plans are underway to digitally rectify the 1:1000-scale photographs and associated crack mapping to produce a scale-constant map.

\section{GEOLOGIC SETTING}

The Granada Hills-Mission Hills deformation belt trends east-west along the south flank of the Santa Susana Mountains (fig. 1). Ground cracks in most of the belt developed across a low-gradient $(\sim 2 \%)$ piedmont in fine-grained Holocene alluvium. Within the eastern third of the belt, cracks developed in Miocene and Pliocene marine sediments and Pleistocene alluvium on the steep southern flank of the Mission Hills anticline (fig. 1).

The deformation belt overlies the east-west-trending Mission Hills anticline and its buried equivalent to the west, and many of the ground cracks lie along possible surface projections of concealed north-dipping reverse faults within the Mission Hills fault zone (fig. 1). These structures have been inferred based on topographic evidence, subsurface oil well data, and seismic-reflection profiles (Barrows, Kahle, and others, 1975a; Shields, 1977; Dibblee and Ehrenspeck, 1991,1992; W. Bartling, unpublished data). The buried anticline apparently comes to the surface west of the study area, in the Santa Susana Mountains, as the Mission anticline (Shields, 1977).

The deformation belt nearly abuts, but is slightly south of, the western end of surface faulting produced by the 1971 San Fernando earthquake (fig. 1). The area of 1994 deformation experienced little surface disturbance during the 1971 earthquake, except for some minor cracks that were observed at several localities (Barrows, Kahle, and others, 1975b). The Northridge earthquake caused cracking to recur at or near most of these localities.

\section{CHARACTERISTICS OF GROUND DEFORMATION}

Deformation in the Granada Hills-Mission Hills area can be subdivided into a) zones where deformation is concentrated and observable in bare ground and b) intervening areas where deformation is more sparsely distributed and generally limited to surficial cracks in pavement (fig. 1). The physiographic setting and character of ground deformation in the zones vary across the broader belt of ground cracks; these aerial variations serve as the organizational basis for this section of the report.

\section{West of Bull Canyon}

The most intensive ground deformation and damage in the Granada Hills-Mission Hills belt occurred in a 1-km-long by $0.5-\mathrm{km}$-wide area located west of Bull Canyon and north of Rinaldi Street (plate 2). In addition to damaging pavement and buildings, ground cracking ruptured several buried utility lines beneath Balboa Blvd., including a $55 \mathrm{~cm}$ (22") high-pressure natural gas main, a $15 \mathrm{~cm}\left(6^{\prime \prime}\right)$ natural gas 
distribution pipeline, and two water trunk lines $(124 \mathrm{~cm}$ (49")and 173 cm (68') diameter)(O'Rourke, 1994; O'Rourke and Palmer, 1994). Leaking gas ignited, and the ensuing fire destroyed five nearby houses and partially damaged a sixth (see plate 2 , locality 1a; fig. 2).

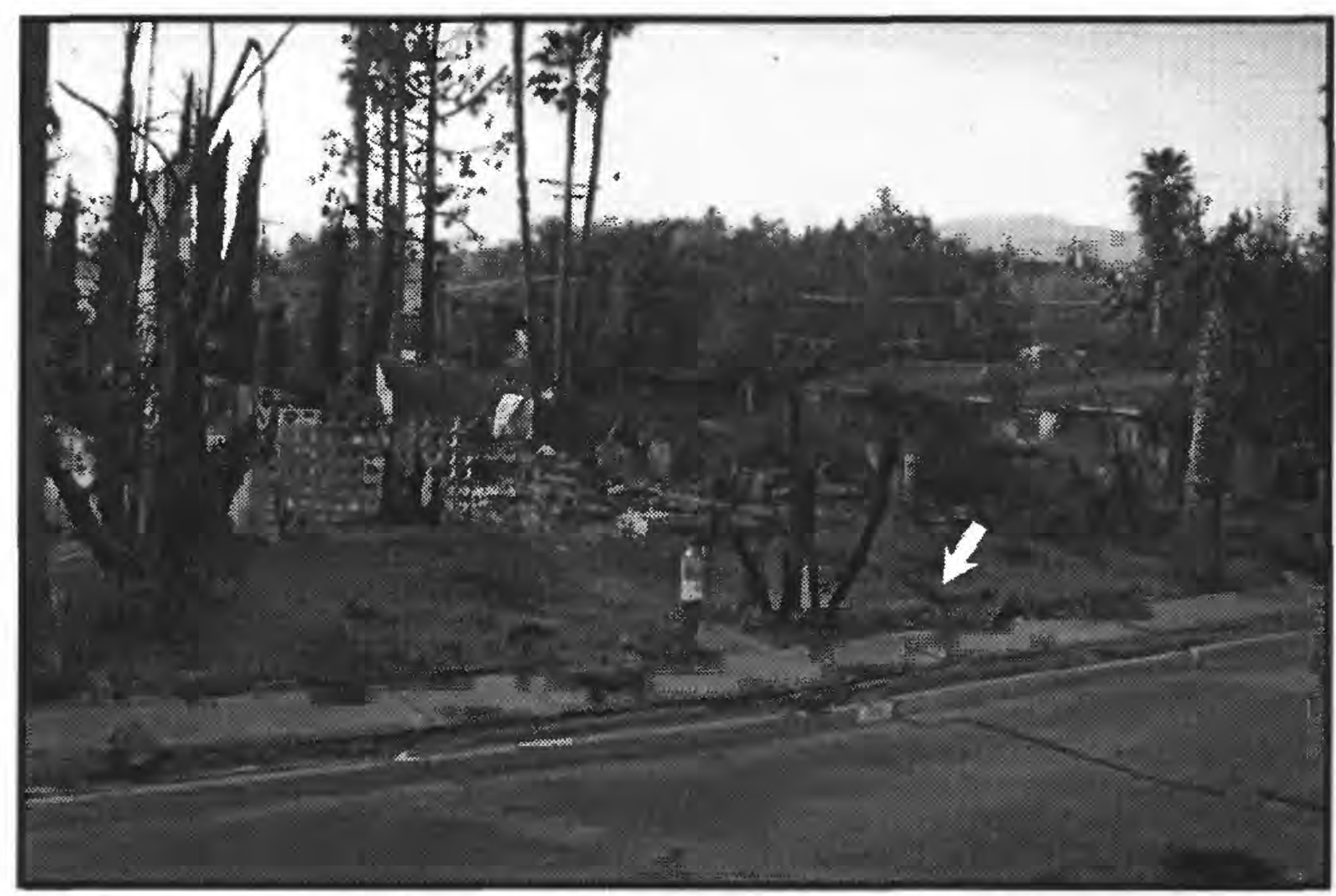

Figure 2. View to northwest of principal zone of tension cracks and one of five houses destroyed by fire on Balboa Blvd. (west of locality 1a, plate 2). Tensile failure of gas lines beneath the street (to the right of view) led to the fire. Note large ground crack (arrow; see fig. 3), with southeast-side-down vertical separation. Photo by M.J. Rymer.

The map of cracks in the area west of Bull Canyon documents several semi-arcuate subzones of dominantly extensional ground cracks that are consistent with southeastdirected ground movement during the earthquake. The most prominent subzone of tension cracks locally reaches a width of $50 \mathrm{~m}$ and extends westward from Bull Canyon to approximately Amestoy Ave. (plate 2). This subzone crosses Balboa Blvd. (fig. 2) where the pipelines failed in tension. Less well defined subzones of tension cracks are observed in the area bounded by McClennan Ave., Rubio Ave., Armstead St., and Halsey St. (plate 2). Individual ground cracks in these subzones are typically several meters long and rarely extend for more than a few tens of meters. The cracks trend mostly northeast to east-southeast and display a component of lateral slip that varies depending on the specific angular relation between their orientation and the ground-movement direction. Azimuths of horizontal vectors measured across individual ground cracks range from $130^{\circ}$ to $170^{\circ}$ (plate 2). This direction of movement is roughly parallel to the area's topographic gradient (fig. 1). Vertical displacements, where present, are generally down to the southeast. Amounts of vertical and horizontal displacement are rarely more than a few $\mathrm{cm}$ per crack, although some cracks display as much as $25 \mathrm{~cm}$ of vertical separation (fig. 3). Unlike the rest of the ground deformation west of Bull Canyon, tension cracks adjacent to Bull Creek indicate east- to northeast-directed movement that is normal to the stream cut and probably is the result of incipient slope failure toward the channel (plate 2, locality 2).

A few hundred meters south of the subzones of extensional deformation is an approximately east-west-trending subzone, coincident or on-line with Flanders St. (plate 2), that contains a number of compressional features. The compression is generally expressed as tenting, buckling, and thrusting of concrete slabs and pavement (fig. 4), especially where walkways and driveways abut roads. Compression at the surface in bare ground is not noted (other than localized mounding of soil against slabs), but the earthquake did cause pipelines beneath Balboa Blvd. to be compressed $\sim 25$ $\mathrm{cm}$ within this subzone (O'Rourke and Palmer, 1994). Evidently, compressional stresses were sufficient to deform brittle surface layers and rigid buried pipelines, but were insufficient to create noticeable deformational structures in bare ground where much of the displacement may have been absorbed within the soil.

The location and orientation of individual surface cracks in the area west of Bull Canyon, and in much of the Granada Hills-Mission Hills belt, are commonly controlled by cultural features, such as roads or houses. These features typically either deflected the ground cracks or broke apart as they decoupled from the underlying ground during seismic shaking. Decoupling and differential movement caused roads and other thin surface slabs to break apart over distances that are commonly broader than the adjacent zone of ground cracks (plate 2). Slab decoupling may also explain the isolated occurrences of compressional features (such as tented and overlapped sections of sidewalks, popped curbs, and buckled pavement; fig. 4) within the zones of tension cracks, and points to the difficulty inherent in interpreting kinematic data from pavement breaks. Because of these complications, we measured crack-specific displacement vectors only in natural ground.

\section{Lower Bull Canyon and Drainageways to the East}

Another area of concentrated ground deformation in the GranadaHills-Mission Hills belt lies east of the areadescribed 


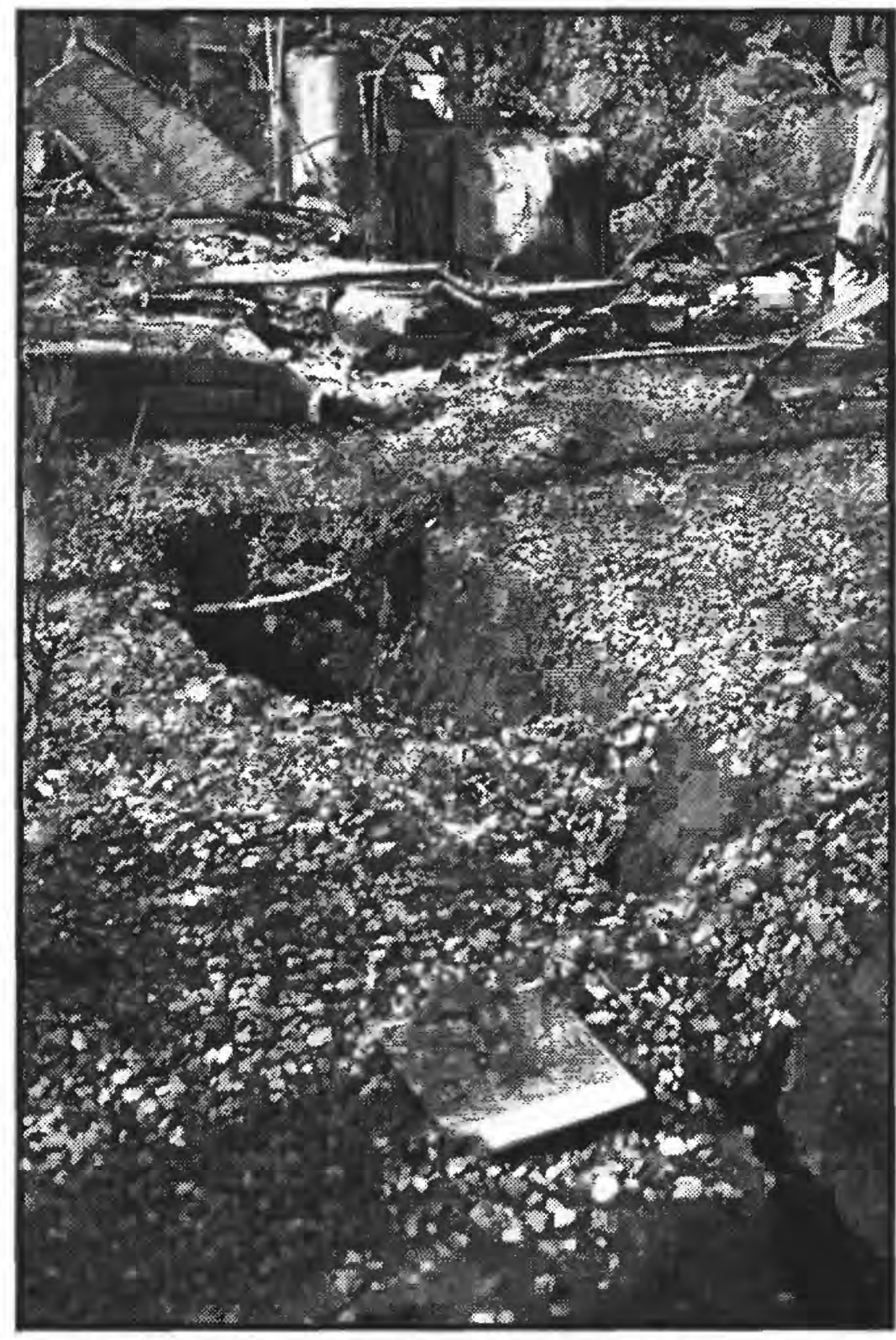

Figure 3. Close up view (to northwest) of large ground crack where it disappears beneath remnants of bumed house at 11661 Balboa Bivd. (fig. 2). Measurements at this site document $22 \mathrm{~cm}$ of southeast-sidedown vertical separation at the ground surface. The crack was widened considerably by caving owing to the surface flooding that followed rupture of nearby water mains. Photo by S. Hecker. above and follows the historical (pre-development) course of Bull Creek through the lower portion of Bull Canyon. Cracks are observed in asphalt, concrete, and bare ground along a reach of the drainage that had been modified through construction of a subsurface storm drain and, at the downstream end, filled for a housing development (plate 2 and fig 5).

A 150-meter-long zone of cracks developed along the stormdrain alignment, on and at the base of the southwest wall of the present channel cut (plate 2, locality 3). Individual cracks are as long as $50 \mathrm{~m}$, have a decimeter or more of opening, and form vertical scarps that face toward the channel (fig. 6). Liquefaction may have contributed to ground failure here, as evidenced by a small area of vented sand on the channel floor near the downstream end of the zone.

Upstream, to the north, a 100-meter-long zone of cracks formed in the middle of the channel floor (plate 2, locality 4) along a pre-existing vegetation lineament that may mark the other side of the storm-drain excavation or some other artificial-fill boundary. A compressional welt and a tension crack with vertical separation down toward the center of the drain form the north and south halves, respectively, of this ground-failure zone. A 30-meter-long crack farther upstream high on the channel wall (plate 2, locality 5) appears to be related to slope failure.

The 150-meter-long crack zone at locality 3 that follows the southwest wall of lower Bull Canyon is part of a longer zone of deformation that continues eastward onto Halsey St. and then southward onto Odessa Ave. (plate 2). These streets follow the course of the old stream bed and are constructed on artificial fill placed in the channel (fig. 5). Topsoil and turf

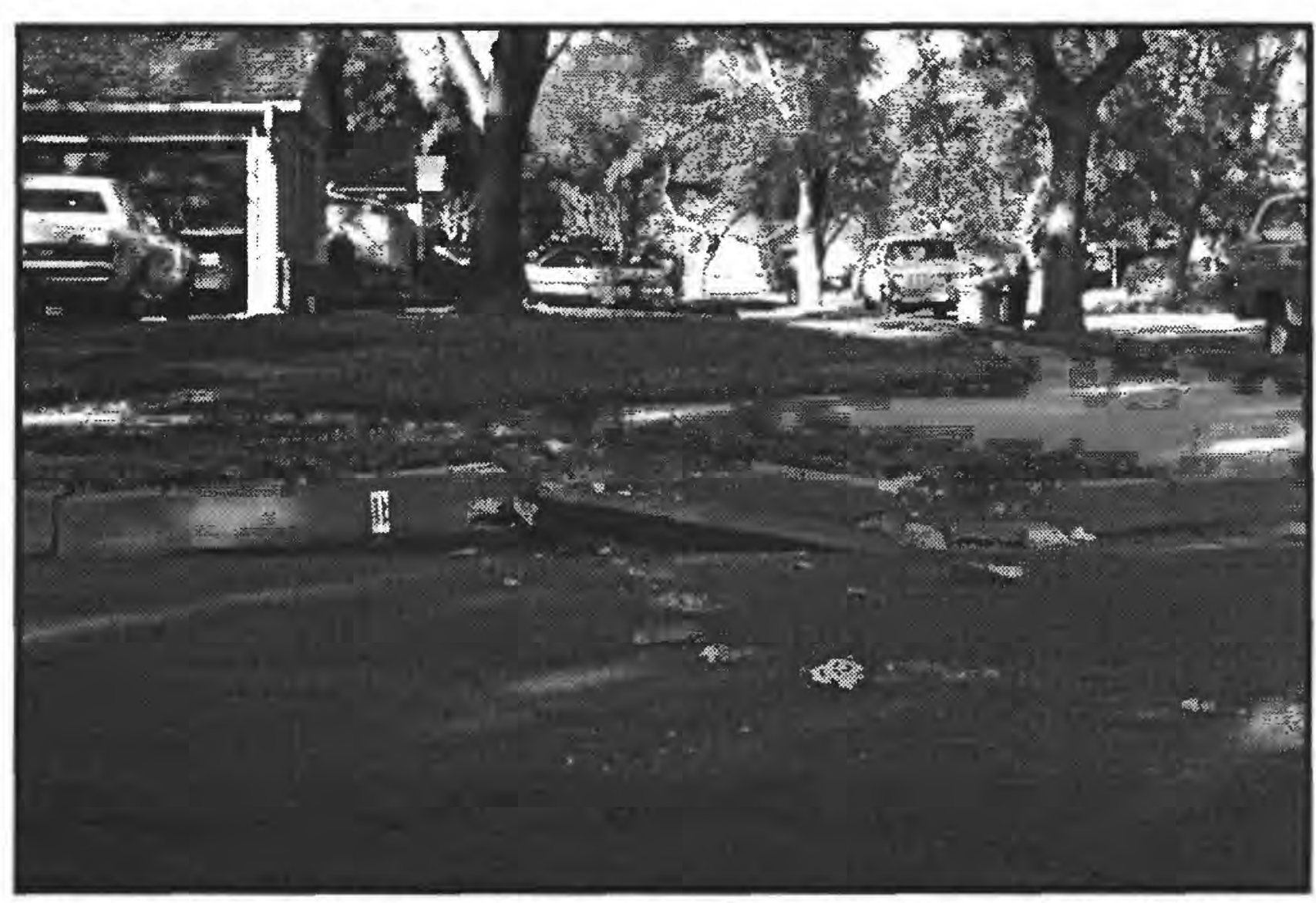

Figure 4. Spalled and thrust-shortened curb at northwest comer of Halsey St. and Ruffner Ave. This type of feature is common in the zone of compression near Flanders St. Photo by M.J. Rymer. 

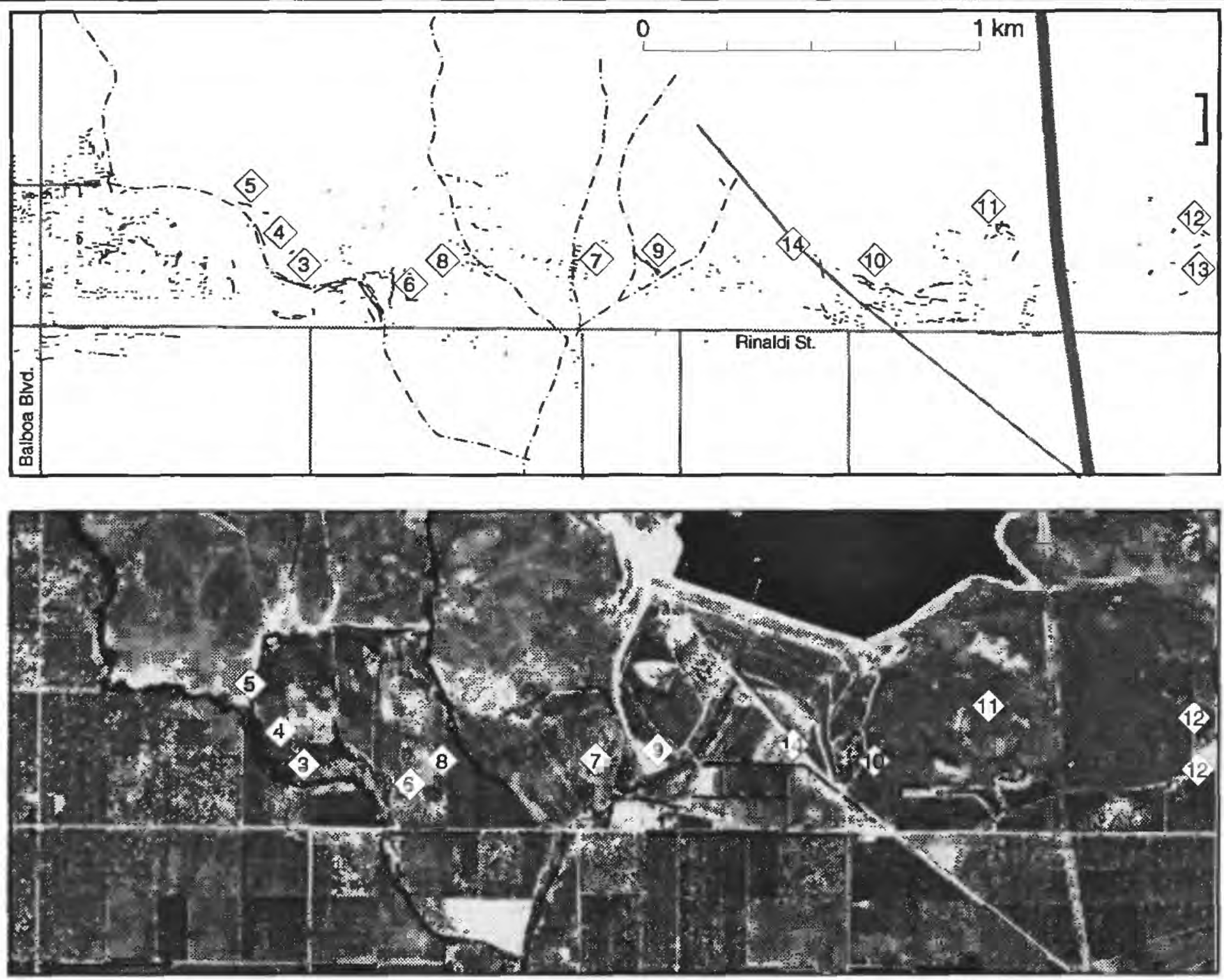

(3) Locality described in text.

Figure 5. 1947 aerial photograph (U.S. Geological Survey, number GS-EM 5-46) of the Granada Hills-Mission Hills area showing location of drainage channels prior to urbanization. Many of the ground cracks that formed in 1994 (shown in line drawing) are adjacent to or overlie these old channels (localities 3-9). Note particularly the geometry of the ground cracks at locality 6 and the existence of an abandoned meander bend at the same location.

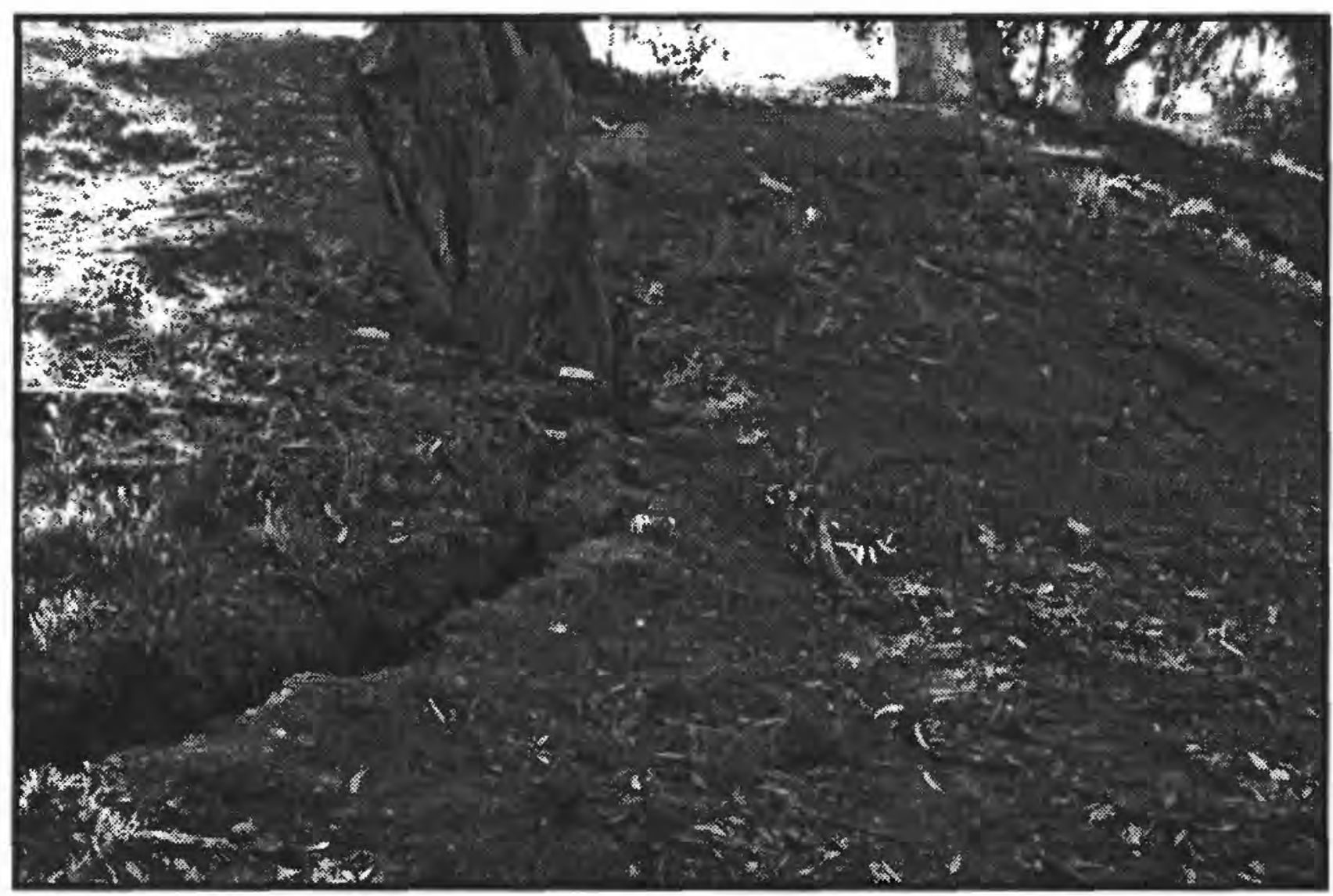

Figure 6. Tension crack on the southwest wall of the Bull Creek channel (view to the west; near locality 3 , plate 2). Photo by T. E. Fumal. 
mounded against the sidewalk on the south and west sides, respectively, of Halsey St. and Odessa St. (fig. 7) and pavement compressed against concrete curbs on the other sides of these roads are evidence for compression orthogonal to both Halsey and Odessa Streets. Tension cracks formed parallel to the compressional features, but they are less extensive and record less movement (typically $\sim 1-2 \mathrm{~cm}$ opening versus $\sim 5 \mathrm{~cm}$ shortening). A series of closely spaced tension cracks also developed transverse to Odessa Ave. (plate 2). Another zone of tension cracks takes a path through several houses and lots east of Odessa Ave. (plate 2, locality 6). As shown in fig. 5, these cracks follow an abandoned meander bend along the old incised channel of Bull Creek.

\section{Mission Hills}

Two subzones dominated by tension cracks and small normal-fault scarps developed low on the south flank of the Mission Hills anticline west of Interstate 405 (fig. 8). The subzones are each about $350 \mathrm{~m}$ long, approximately parallel, and cross from open ground into a densely developed housing complex (plate 1, locality 10 ). The cracks follow the general contour of the moderately steep ( $15 \%$ gradient) hillside and appear also to follow bedding planes in the upper Miocene Modelo Formation and the upper Miocene and lower Pliocene Towsley Formation, which dip in the downslope direction ( $60-70^{\circ}$ to the south; Dibblee and

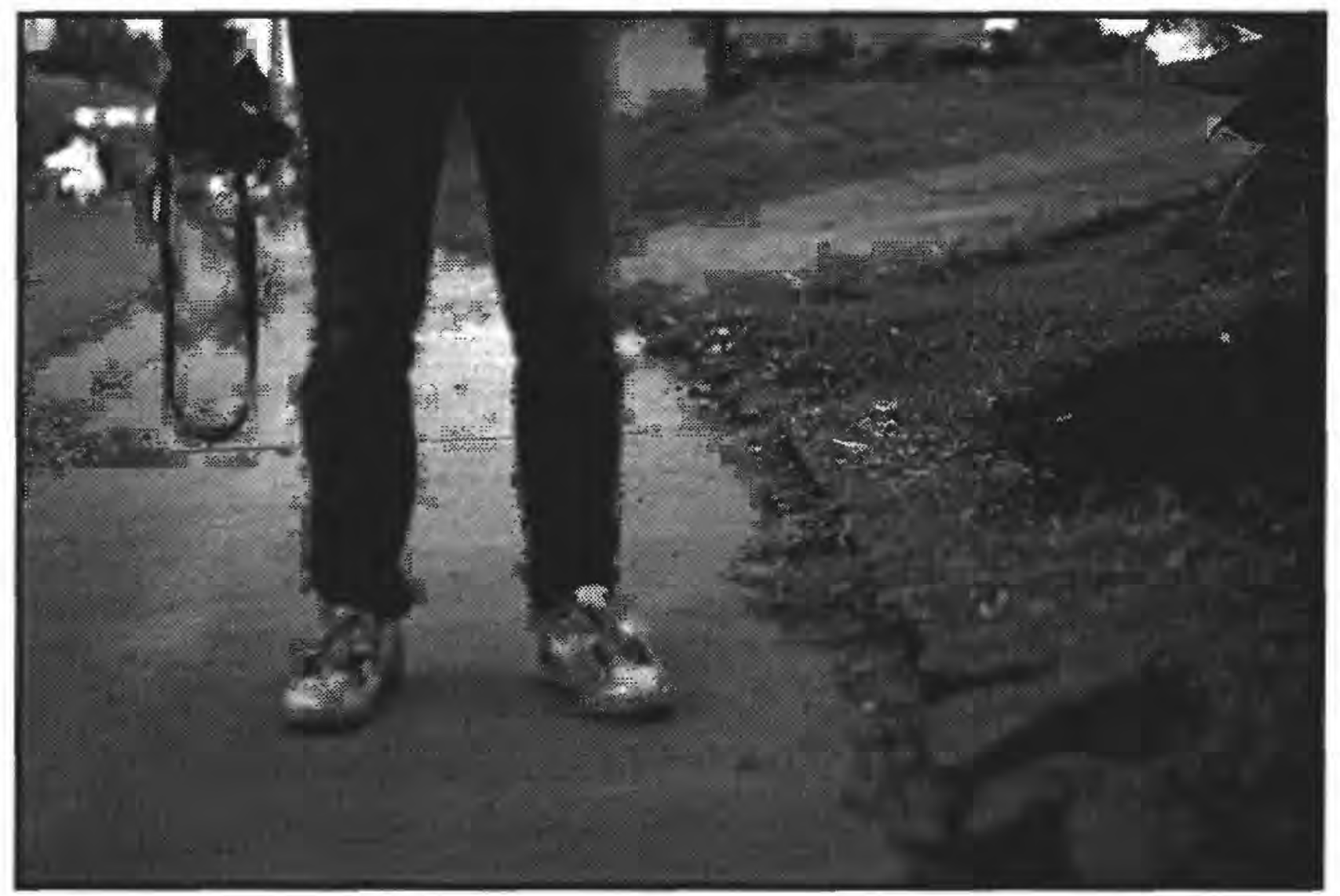

Figure 7. Topsoil and turf thrust over sidewalk along the west side of Odessa Ave. View to the south. Photo by D.P. Schwartz.

Other roads built on artificially filled channels were also damaged during the earthquake. A set of transverse cracks formed on Woodley Ave., a road that replaced a small tributary drainage of Bull Creek (plate 1 and fig. 5, locality 7). In addition, a local concentration of road-parallel deformation developed along a northwest-trending segment of Halsey St., near where it joins with Gothic Ave. to mark the former course of another tributary stream (plate 1 and fig. 5, locality 8).

Ground cracksalso developed across the campus of Kennedy High School, which is built above a buried, channelized portion of Bull Creek just south of our study area (see plate 1, between Woodley Ave. and Highway 118). Ground deformation at the school may reflect permanent lateral movement of subsurface material toward the channel, as apparently occurred farther upstream along the open but channelized eastern branch of Bull Creek. At this location within the study area (plate 1, locality 9), a zone of tension cracks developed in nearly level ground adjacent to the channel.
Ehrenspeck, 1991; Barrows, Kahle, and others, 1975a). The amount of horizontal extension measured on cracks in each subzone is generally less than $5 \mathrm{~cm}$, although more than $10 \mathrm{~cm}$ of extension is observed along the middle portion of the upper subzone of cracks. A small side-hill bench, along which graben and other cracks formed during the earthquake, is present within the upper subzone and is evidence that ground movement had occurred here previously. Where the two subzones cross into the area of multi-family housing on the hillside, they are expressed as diversely oriented cracks in roads, driveways, walkways, and storm drains.

A third zone of minor tension cracks lies beyond the base of the hillside and fractures a graded dirt parking lot next to an electrical substation (plate 1).

Three other areas of ground cracks formed on the Mission Hills anticline during the earthquake. One zone of tension cracks, approximately $100 \mathrm{~m}$ long and $60 \mathrm{~m}$ wide, developed next to an apartment complex on a cut-and-fill slope in Pleistocene alluvium high on the south-facing hillside west of I-405 (plate 1, locality 11). This zone has an arcuate shape that is concave downslope, suggestive of a landslide crown. Another area of cracks occupies a similar setting east of I405. Here, tension cracks on the hillside developed upslope from a compressional welt that formed locally on the inside edge of a large cut bench (plate 1, localities 12 and 13). A third zone of cracks is aligned along the western base of the anticlinal hill, perpendicular to the axis of the Mission Hills anticline (plate 1 , locality 14 ). This line of cracks is about $150 \mathrm{~m}$ long and follows the upper end of a small, pre-existing landslide, which appears to have developed in colluvial deposits at the foot of the hillslope. 


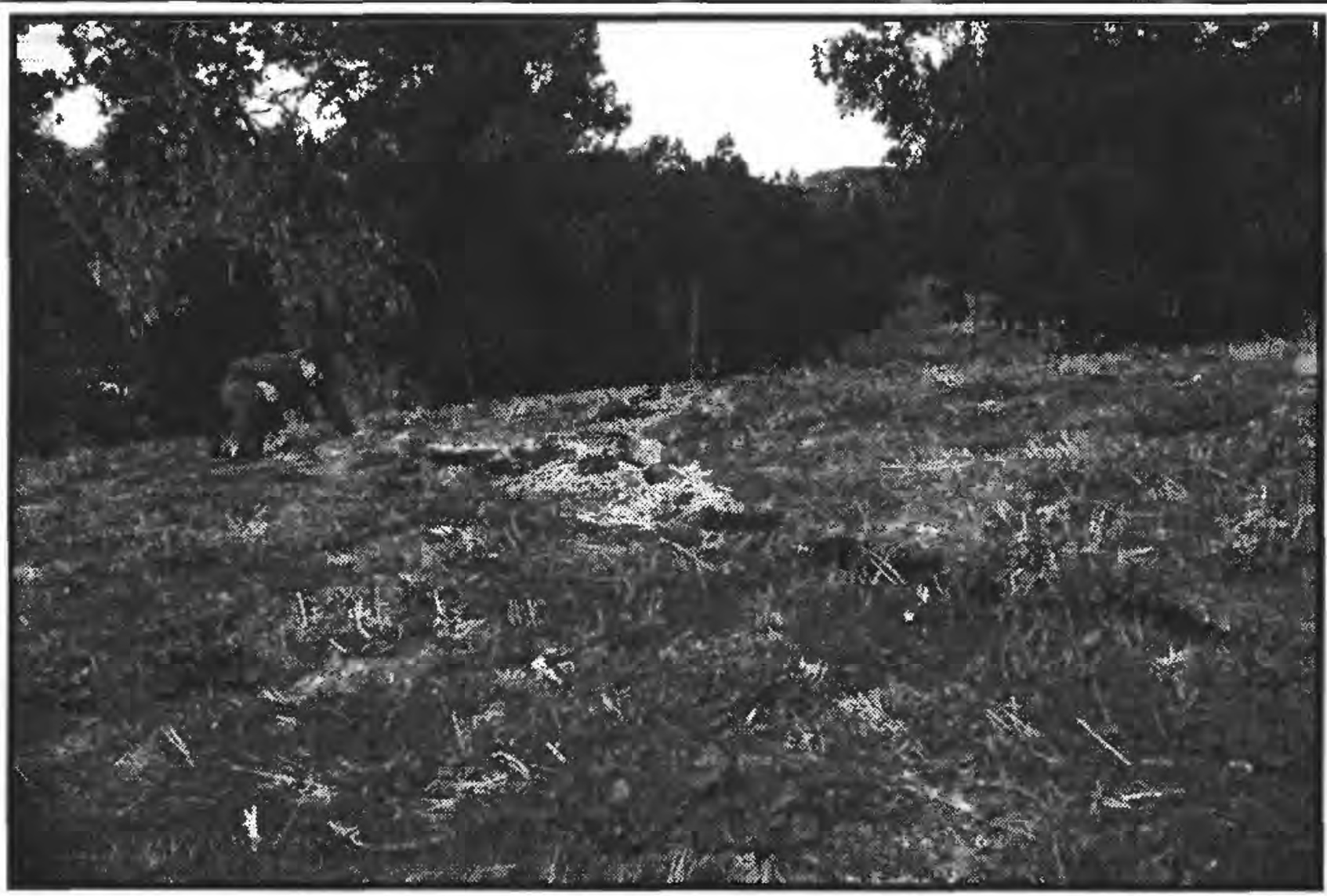

Figure 8. Tension crack and small scarp on south flank of the Mission Hills anticline (near locality 10, plate 1). View to the northwest. Photo by C.D. Garvin.

\section{ORIGIN OF GROUND DEFORMATION}

In the area west of Bull Canyon, the pattern of tension cracks and compressional deformation is suggestive of surficial mass movement. Pertinent features are: 1) a somewhat arcuate crown scarp defined by the principal subzone of tension cracks that crosses Balboa Blvd.; 2) internal scarps developed in the vicinity of Bircher St.; 3) a poorly defined lateral margin in the vicinity of Ruffner Ave., and 4) a compressional toe expressed along Flanders St. (refer to plate 2). Furthermore, the direction of ground movement (to the southeast) closely parallels the local topographic gradient, and crack trends are strongly influenced by small-scale topographic variations. For example, the principal, northeast-trending subzone of cracks that crosses Balboa.Blvd. abruptly turns southeast to run along the rim of the 7-9 $\mathrm{m}$ deep Bull Canyon incision instead of continuing across it (plate 2). This line of evidence suggests that deformation is confined to within $\sim 10$ meters of the ground surface. Surveys of longitudinal (length-wise), lateral, and vertical components of road deformation in the area, part of a broaderscope study, provide independent evidence for shallow, southeast-directed ground failure west of Bull Canyon (Hecker, Ponti, and others, 1995). The orientation of ground movement derived from these data $\left(133^{\circ}-164^{\circ}\right)$ is consistent with the range of displacement-vector azimuths measured on individual cracks $\left(130^{\circ}-170^{\circ}\right.$; plate 2$)$. Total horizontal displacement of roads varies from 22 to $60 \mathrm{~cm}$ across the zones of tension cracks (Hecker, Ponti, and others, 1995).

Downslope mass movement appears to best account for the set of deformation characteristics observed west of Bull Canyon, but the reasons for ground failure here are unclear.
The gradient is gentle $(\sim 2 \%)$, so the area does not appear especially susceptible to slope failure. Also, we are unaware of any subsurface horizons with low shear strength that could accommodate a slide plane. However, little is known about subsurface conditions in the area, beyond a general understanding that the piedmont is formed on predominantly fine-grained Holocene alluvium. Liquefaction may have played a role in ground failure, but no evidence for liquefaction was observed at the surface, and no evidence exists for widespread shallow ground water. In most of the region, the ground water table may be $>30 \mathrm{~m}$ beneath the surface (California State Water Rights Board, 1962), although recent borings drilled adjacent to Bull Canyon encountered water at a depth of $\sim 9 \mathrm{~m}$ (F. Dennison, consulting geologist, pers. communication, 1994). Regardless of the particular sedimentologic and hydrologic factors involved, ground motion is likely a necessary component of the mechanics of failure and downslope movement in this lowgradient area.

Zones of tension cracks on the south flank of the Mission Hills anticline accommodated downslope-directed movement on steep slopes, and all but perhaps the two most extensive zones are clearly expressions of shallow slope failure. Cracks in the two 350 -meter-long zones on the hillside west of the I-405 freeway, which conform to the attitude of bedding in the underlying bedrock, have displacements consistent with bedding-plane faulting and, thus, may have accommodated arching and extension during possible coseismic folding of the anticline. Alternatively, the bedding surfaces could have acted to control the geometry of slip planes within an incipient landslide complex. This is a postulated mechanism for ground cracks produced in the 
Santa Cruz Mountains by the 1989 Loma Prieta earthquake (Ponti and Wells, 1991).

There is little suggestion of tectonic surface faulting in the rest of the Granada Hills-Mission Hills belt of deformation. Cracks along Bull Creek and its tributaries are directly associated with natural or artificial channel fill and were evidently caused by liquefaction and/or shaking-induced compaction of the fill and possibly of young, fine-grained stream deposits. Cracks on or near channel walls probably resulted from slope failure as well. Small sand boils, evidence of liquefaction, formed on the floor of lower Bull Canyon at a location just upstream from Halsey St. and the filled portion of the channel. In the vicinity of Halsey St. and Odessa Ave., which were both constructed along the former course of Bull Creek, the ground cracks are likely an expression of lurching or differential compaction between the artificial fill or the underlying stream deposits and the adjacent piedmont alluvium. Shaking-induced lurching of material probably explains the combination of tension cracks that follow the old meander-bend channel margin east of Odessa Ave. and the compressional features observed within the road itself, above the old stream bed (fig. 5). However, moisture- or deposition-related differences in the response of the stream deposits to shaking may have also contributed to the pattern of deformation seen along the two roads. Cracks were also observed here locally following the 1971 San Fernando earthquake (Barrows, Kahle, and others, 1975b), a further indication that ground shaking may be an underlying cause of deformation in this area.

The characteristics of ground deformation across the Granada Hills-Mission Hills belt vary in detail, but cracks in all of the zones appear to reflect control by local topographic and near-surface geologic conditions. Although most of the deformation appears to be an expression of shallow ground failure, site-specific mechanisms of failure generally are not known. The origins of deformation probably vary among zones and may involve one or more of the following shallow-seated phenomena: slope failure, lurching of surficial deposits, compaction of loose sediment, and liquefaction. The shallow nature of most or all of the deformation indicates that the belt as a whole is not a direct expression of tectonic surface faulting or of tectonic deformation due to subsurface faulting and folding. Moreover, the above-postulated deformation phenomena largely require that ground motion was an integral part of the deformation process in the region.

\section{RELATION OF GROUND DEFORMATION TO DAMAGE PATTERNS}

Judging from effects of the 1989 Loma Prieta earthquake, damage from ground deformation in non-surface-faulting earthquakes is relatively inconsequential (Holzer, 1994). However, in the case of the Loma Prieta earthquake, the largest and greatest concentration of ground deformation occurred in rural areas (U.S. Geological Survey Staff, 1990). In contrast, the Northridge earthquake produced significant ground cracks in developed areas and therefore offers an excellent opportunity to assess the earthquake risk from secondary ground deformation in a suburban environment. Such an assessment is important for cost-effective mitigation.

Damage to well constructed and maintained infrastructure (roads and utilities) in Granada Hills and Mission Hills appears largely due to earthquake-induced ground deformation. Damage occurs at most locations where zones of ground cracks cross infrastructure corridors. More importantly, earthquake damage is largely nonexistent in areas where ground cracks are absent. Exceptions are largely limited to pipeline failures attributable to corrosion or poor welds (T. O'Rourke, pers. communication, 1994). Shakinginduced decoupling of roads and sidewalks generally enhances damage such that fracture zones are typically broader and more extensive in pavement than in adjacent bare ground (e.g., see plate 2, along Balboa Blvd. and Paso Robles Ave.).

The relation between ground deformation and structural damage is more difficult to discern. Most structures in the Granada Hills-Mission Hills deformation belt are relatively modern ( $<30$ years old), one- or two-story, single-family wood-frame houses. Many of the houses are built on slab foundations that are not steel-reinforced. Despite the high ground accelerations, buildings of similar vintage and construction within the greater San Fernando Valley generally performed quite well, and typically sustained only cosmetic damage. In the Granada Hills-Mission Hills area, however, many structures appear to have experienced significant structural damage.

To assess the spatial relation between structural damage and permanent ground deformation in the area west of Bull Canyon, we've compared the locations of houses determined to be safety concerns as of March 17, 1994 (inspection-tagged either "red", which bars entry, or "yellow", which limits entry), with the locations of cracks (plate 2). As shown on plate 2, tagged buildings commonly lie over or adjacent to mapped cracks, and the general pattern of damage largely reflects the pattern of deformation. The correlation between damage and deformation is especially evident along the northeast-trending subzone of tension cracks between Bull Creek and Paso Robles Ave. and within the subzone of compression along Flanders St.. Many structures within the crack zones had suffered cracking and displacements within their foundations as well (fig. 9). Based on these observations, we suggest that structural damage in the area is largely the result of the permanent ground deformation that accompanied formation of the ground cracks. This evaluation is preliminary, because the damage information we received in March of 1994 is not complete. Factors other 


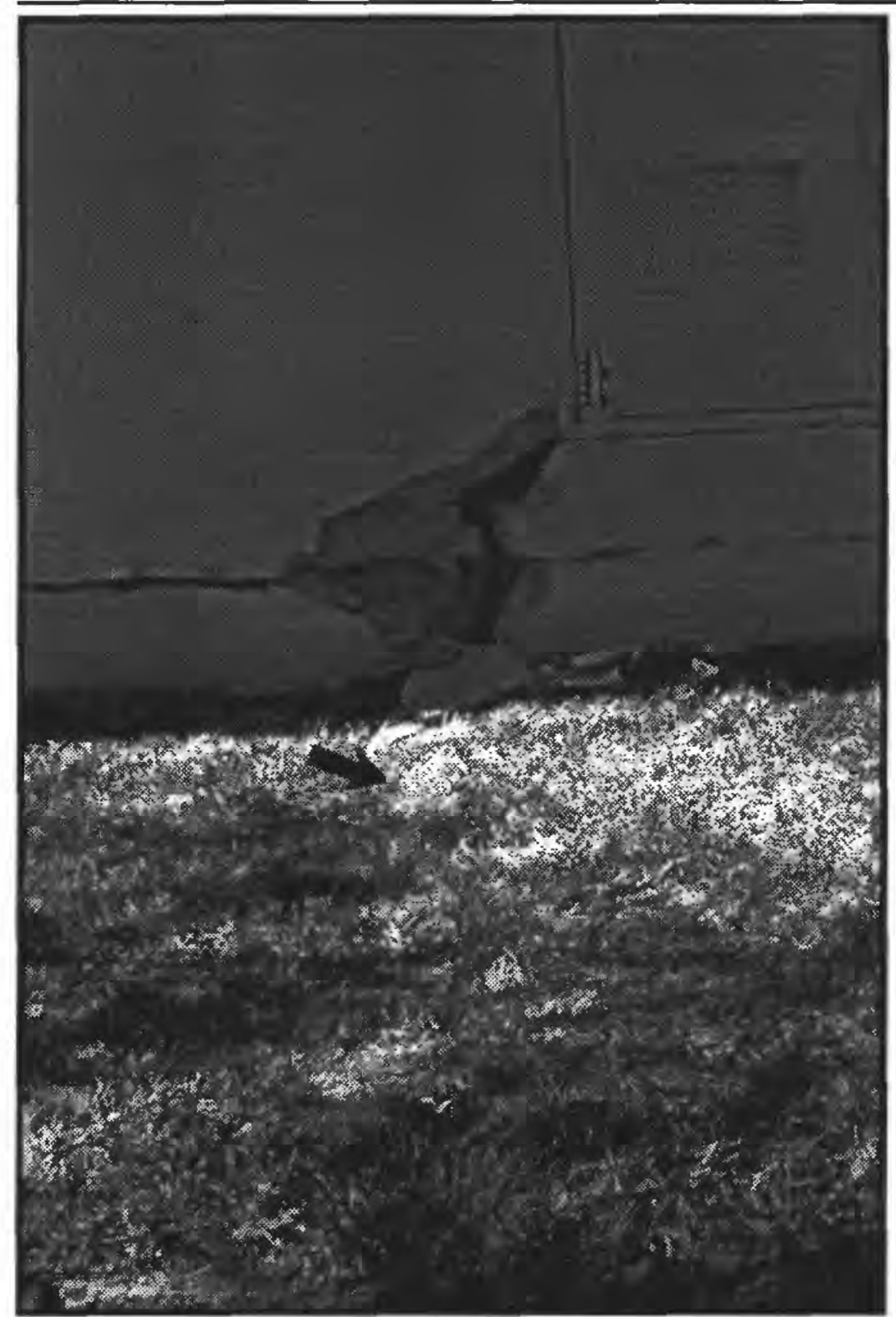

Figure 9. Foundation slab of a house broken by a ground crack (arrow), south side of Armstead St. The house was one of two on the street that were substantially damaged and assigned "red" inspection tags (plate 2). Photo by M.J. Rymer.

than ground deformation, such as building design and construction practices, may account for a sizable proportion of damage, and we are gathering additional information on the full scope of damage in the area. Clearly, however, ground deformation contributed significantly to the structural damage observed in the Granada Hills-Mission Hills area.

\section{DISCUSSION AND CONCLUSIONS}

The character and pattern of ground deformation in the Granada Hills-Mission Hills area lead us to conclude that the primary mechanism for the deformation is shallow ground failure induced by strong shaking. Shaking is a viable mechanism for the concentration of ground deformation in the Granada Hills-Mission Hills area, as large ground motions were experienced here during the main shock. The peak ground acceleration recorded by a strong motion instrument at the LADWP Rinaldi Receiving Station (fig. 1) is ratherhigh $(0.83 \mathrm{~g})$, but the peak velocity here, which is more indicative of ground strains, is the highest recorded for any earthquake anywhere (Wald and Heaton, 1994). In addition, a large aftershock $\left(\mathrm{M}_{\mathrm{L}}=5.9\right)$ occurred directly beneath the Mission Hills (fig. 1) only 62 seconds after the main shock and may have exacerbated strong shaking locally. The Mission Hills fault, which projects to the surface along the deformation zone, may have contributed to the high ground motions by either focusing or releasing seismic energy. Any displacement on the fault accompanied by broad-scale deformation of the ground surface may have helped to trigger the ground failures (Hecker, Ponti, and others, 1995).

Damage surveys in the Granada Hills-Mission Hills area indicate that the socio-economic impact of secondary ground deformation in an urban setting may be significant. However, the overall risk posed by this type of hazard may be small if the time interval between ground-deforming events is long. Preliminary evidence from crack-zone trenching near Balboa Blvd. and in other areas suggests intervals of recurrence may be on the order of 1000 years (Hecker, Ponti, and others, 1995). More work is needed, however, both to better address the recurrence history of the Granada HillsMission Hills deformation belt and to evaluate the regional extent of the hazard, before risk can be assessed confidently.

The results of this study suggest that areas near the up-dip projection of a concealed fault zone that are underlain by young, unconsolidated sediment or steeply dipping bedrock may be especially susceptible to ground failure during an earthquake. Our understanding of the geologic conditions conducive to ground failure could be the basis for effective mapping of ground-failure susceptibility zones that, depending on the magnitude of the risk, could lead to significant reductions in economic losses in future earthquakes.

\section{REFERENCES}

Barrows, A.G., Kahle, J.E., Saul, R.B., and Weber, F.H., Jr., 1975a, Geologic map of the San Fernando earthquake area, in Oakeshott, G.B., ed., San Fernando, California, earthquake of 9 February, 1971: California Division of Mines and Geology Bulletin 196 plate 2, scale 1:18000.

Barrows, A.G., Kahle, J.E., Weber, F.H., Jr., Saul, R.B., and Morton, D.M., 1975b, Surface effects map of the San Fernando earthquake area, in Oakeshott, G.B., ed., San Fernando, California, earthquake of 9 February, 1971: California Division of Mines and Geology Bulletin 196, plate 3, scale 1:24000.

California State Water Rights Board, 1962, Report of Referee, City of San Fernando, California Superior Court, County of Los Angeles: California State Water Rights Board, report 650079 , v. 1, 258 p.. 
Dibblee, T.W., and Ehrenspeck, H.E., 1991, Geologic map of the San Fernando and Van Nuys (north 1/2) quadrangles, Los Angeles County, California, Dibblee Geological Foundation, scale 1:24000.

Dibblee, T.W., and Ehrenspeck, H.E., 1992, Geologic map of the Oat Mountain and Canoga Park (north 1/2) quadrangles, Los Angeles County, California, Dibblee Geological Foundation, scale 1:24000.

Goltz, J.D., ed., 1994, The Northridge, California earthquake of January 17, 1994: General Reconnaissance Report, National Center for Earthquake Engineering Research, Technical Report NCEER-94-0005, 130 p.

Hecker, S., Ponti, D.J., Garvin, C.D., and Hamilton, J.A., 1995, Characteristics and origin of ground deformation in Granada Hills and Mission Hills during the January 17, 1994 Northridge, California, earthquake, in Woods, M., and Seiple, W.R., eds., The Northridge, California, earthquake of January 17, 1994, California Department of Conservation, Division of Mines and Geology Special Publication 116, in press.

Holzer, T.L., 1994, Loma Prieta damage largely attributed to enhanced ground shaking: EOS Transactions of the American Geophysical Union, v. 75, no. 26, p. 299-301.

O'Rourke, T.D., 1994, Water system damage during the Northridge earthquake: NCEER Bulletin, v. 8, no. 2, p. 6-8.

O'Rourke, T.D., and Palmer, M.C., 1994, Earthquake performance of gas transmission pipelines during the Northridge earthquake: NCEER Bulletin, v. 8, no. 2, p. 1-5.

Ponti, D.J., and Wells, R.E., 1991, Off-fault ground ruptures in the SantaCruzMountains, California: ridge-topspreading versus tectonic extension during the 1989 Loma Prieta earthquake: Bulletin of the Seismological Society of America, v. 81, no. 5, p. 1480-1510.

Shields, K.E., 1977, Structure of the northwestern margin of the San Fernando Valley, Los Angeles County, California, Ohio University, M. S. Thesis, 82 p.

U.S. Geological Survey Staff, 1990, The Loma Prieta, California earthquake: an anticipated event: Science, $v$. 247, p. 286-293.

Wald, D.J., and Heaton, T.H., 1994, A dislocation model of the 1994 Northridge, California, earthquake determined from strong ground motions: U.S. Geological Survey Open-File Report 94-278, 54 p. 